Prikaz

Rukopis primljen 8. 8. 2017.

Prihvaćen za tisak 9. 10. 2017.

https://doi.org/10.22210/govor.2017.34.05

\title{
Zdravka Biočina
}

zbiocina@windowslive.com

Zagreb

Radionica o izazovima $\mathrm{u}$ analizi i obradi spontanoga govora CAPSS2017. Budimpešta, Mađarska, od 14. do 17. svibnja 2017.

Prva radionica o izazovima $\mathrm{u}$ analizi i obradi spontanoga govora održala se $\mathrm{u}$ Budimpešti od 14. do 17. svibnja 2017. godine u organizaciji Odsjeka za fonetiku Instituta za lingvistiku Mađarske akademije znanosti. Ovo je bila prva u nizu CAPSS radionica koja će se održavati svake dvije godine i koja će okupljati istraživače raznih znanstvenih područja koji se bave spontanim govorom.

Radionica je održana u Institutu za lingvistiku Mađarske akademije znanosti koji je smješten u blizini Trga heroja, najpoznatijega i najvećega trga u Budimpešti. Sesije su se održavale u jednoj od prostorija na prvome katu Instituta, što je bio odličan izbor, budući da su svi sudionici bili okupljeni na jednome mjestu.

Ukupno je održano 25 usmenih izlaganja, jedna demonstracija te četiri pozvana plenarna izlaganja. Svaki dan radionice započeo je pozvanim plenarnim izlaganjem, a u utorak, 16. svibnja na rasporedu su bila čak dva plenarna predavanja. Osim brojnim pozvanim plenarnim izlaganjima, radionica se istaknula i raznovrsnim temama koje su bile zastupljene, a koje su vezane za spontani govor.

Prvo plenarno izlaganje bilo je ono prof. dr. sc. Valerie Hazan pod naslovom Spontaneous speech adaptations in challenging communicative conditions across the lifespan "Prilagodbe u spontanome govoru u zahtjevnim komunikacijskim uvjetima tijekom života" u kojem su predstavljene tri studije o spontanome govoru. Autorica je istraživala utjecaj dobi i spola na spontani govor te akustičko-fonetske adaptacije prilikom spontanoga govora u bučnome okruženju.

Drugo, vrlo zanimljivo plenarno izlaganje o interaktivnoj sintezi govora i komunikaciji između robota i čovjeka pod naslovom Towards interactive speech synthesis; an example of robot-human dialogues in a spontaneous environment "Ka interaktivnoj sintezi govora; primjer dijaloga robota i čovjeka u spontanome 
okruženju" održao je professor emeritus Nick Campbell. U izlaganju je, između ostalog, prikazano kako se prikuplja korpus spontanoga govora u jednome muzeju uz pomoć robota (Herme robot) koji je sposoban voditi kraće razgovore s posjetiteljima. Predavač je govorio i o prednostima interaktivne sinteze govora. U utorak popodne održano je i treće plenarno izlaganje čija je tematika bila drugačija od plenarnoga izlaganja toga jutra. Prof. dr. sc. Ruth Huntley Bahr izložila je rad Variability in speech sound production: Covert contrasts in the speech of children with cochlear implants "Varijabilnost u proizvodnji govornih zvukova: prikrivena sustavnost u govoru djece $s$ umjetnom pužnicom" u kojem je predstavila rezultate dvaju projekata o usvajanju fonologije kod djece $s$ umjetnom pužnicom. Autorica je dobivene rezultate usporedila $s$ rezultatima djece bez slušnih poteškoća. Posljednje pozvano plenarno izlaganje Neurolinguistic aspects of speech processing "Neurolingvistički aspekti govornoga procesiranja" održala je u srijedu ujutro prof. dr. sc. Vesna Mildner, koja je iscrpno objasnila neurolingvističke osobitosti govornoga procesiranja. Između ostaloga, osvrnula se i na reevaluaciju postojećih teorija s obzirom na dosege u tehnologijama kojima se istražuje funkcioniranje ljudskoga mozga i na posebnosti u procesiranju govora kod dvojezičnih osoba te osoba s govornim teškoćama.

Programski dio radionice zatvorili su Tamás Gábor Caspó, Andrea Deme, Tekla Etelka Gráczi, Alexandra Markó i Gergely Varjasi demonstracijom: Synchronized speech, tongue ultrasound and lip movement video recordings with the "Micro" system.

Čitav je raspored još uvijek dostupan na mrežnim stranicama radionice (http://capss2017.nytud.hu/).

$\mathrm{Na}$ radionici su bila zastupljena i izlaganja studenata. Kako bi potaknuli i nagradili znanstveni rad mladih istraživača, jednom izlagaču, mlađem od 35 godina, dodijeljena je Nagrada za najbolje izlaganje mladog istraživača (CAPSS prize for the best young presenter).

$\mathrm{Na}$ skupu su, osim plenarnoga izlaganja prof. dr. sc. Vesne Mildner s Odsjeka za fonetiku, predstavljena još dva hrvatska istraživanja, također s Odsjeka za fonetiku u Zagrebu. Marko Liker predstavio je rad Electropalatographic analysis of vowels in quasispontaneous speech "Elektropalatografska analiza vokala u kvazispontanome govoru" u kojem je iznio metodologiju i rezultate vlastitoga istraživanja hrvatskih vokala elektropalatografom. U radu Comparison of FO measures for male speakers of Croatian, Serbian and Slovenian "Usporedba mjera fundamentalne frekvencije muških govornika hrvatskoga, srpskoga i slovenskoga jezika" Gordana Varošanec-Škarić, 
Zdravka Biočina i Gabrijela Kišiček izložile su rezultate i usporedile mjere fundamentalne frekvencije mlađih muških govornika iz Hrvatske, Srbije i Slovenije.

U sklopu radionice organizirana su i dva društvena događanja. Na kraju prvoga dana priređena je zabava dobrodošlice uz večeru i piće u Gastland Bisztró Oktogon. To je bila odlična prilika da se sudionici, već na samom početku, bolje upoznaju. Posljednjega je dana radionice održana oproštajna zabava uz kolače i piće na kojoj su sudionici imali priliku nakon trodnevnoga druženja podijeliti doživljaje i dogovoriti buduće suradnje.

Izlagači su imali mogućnost objaviti radove $s$ radionice ili u posebnom izdanju časopisa The Phonetician ili u uredničkoj knjizi koja će biti dostupna na internetu.

Prva je CAPSS radionica pokazala brojne potencijale i otvorila zanimljive teme iz područja spontanoga govora. Brojni pozvani plenarni izlagači, kao i zanimljiva i inovativna istraživanja izlagača, pridonijeli su bogatim raspravama i pitanjima. $\mathrm{Za}$ očekivati je da će, uz ovako dobru organizaciju, Odsjek za fonetiku u Budimpešti i za dvije godine ponovno organizirati uspješnu radionicu. 